\title{
Trophic relations in the subarctic North Pacific ecosystem: possible feeding effect from pink salmon
}

\author{
Akihiro Shiomoto*, Kazuaki Tadokoro, Kazuya Nagasawa, Yukimasa Ishida
}

National Research Institute of Far Seas Fisheries, 7-1, Orido 5 Chome, Shimizu-shi, Shizuoka, 424 Japan

\begin{abstract}
Year-to-year variations in biomass of phytoplankton (surface chlorophyll a concentration) and macrozooplankton (wet weight obtained by NORPAC net operation above $150 \mathrm{~m}$ ), and abundance of pink salmon (catch per unit effort of pink salmon) from 1985 to 1994 in the subarctic North Pacific in summer were studied. After 1989, phytoplankton biomass and pink salmon abundance showed corresponding yearly patterns, whereas the pattern shown by macrozooplankton biomass was always the inverse of that shown by phytoplankton and salmon. We suggest that macrozooplankton biomass remained low when pink salmon was abundant due to the intense feeding impact of pink salmon, which in turn allowed phytoplankton biomass to remain high as a result of the lesser grazing effect of macrozooplankton. The opposite phenomenon probably occurred when pink salmon was not abundant. Prior to 1989, macrozooplankton biomass was at a rather high level while phytoplankton biomass and pink salmon abundance were low. We suggest that macrozooplankton biomass remained high due to a lesser feeding impact of the punk salmon, and phytoplankton biomass remained low due to the intense grazing effect of macrozooplankton. Our study therefore shows the possibility that the feeding effect from the pink salmon controls summer macrozoo- and phytoplankton biomass in the subarctic North Pacific.
\end{abstract}

KEY WORDS: Phytoplankton-Zooplankton Pink salmon Grazing - Feeding Trophic relation Subarctic ecosystem

\section{INTRODUCTION}

A large number of studies on trophic relations in freshwater ecosystems have been carried out. The investigators pointed out the importance of nutrient availability and producers from below (e.g. Dillon \& Rigler 1974, McCauley \& Kalff 1981) or of consumers from above (e.g. Brooks \& Dodson 1965, Carpenter et al. 1985, Scavia et al. 1986) in controlling the biomass at each trophic level. McQueen et al. (1986) furthermore showed that control from below is stronger at lower trophic levels and control from above is stronger at higher trophic levels. In marine ecosystems, too, the fluctuation of biomass at each trophic level has been explained by control from below by physical and

•E-mail: shiomoto@enyo.affrc.go.jp chemical environmental factors and producers (Taniguchi 1973, Motoda \& Minoda 1974, Smith \& Eppley 1982, Venrick et al. 1987, Brodeur \& Ware 1992, Anonymous 1993, Roemmich \& McGowan 1995) or from above by consumers (Dagg \& Turner 1982, Hargrave et al. 1985, Frost 1987, Cooney 1988, Parsons \& Lalli 1988, Miller et al. 1991, Odate 1994, Rundstam et al. 1994).

Taniguchi (1973) found that biomass and food requirements of herbivorous communities are controlled by primary production in the subarctic North Pacific and the adjacent subarctic seas. Brodeur \& Ware (1992) explained the long-term variation of macrozooplankton biomass as control from below by the physical environment in the subarctic North Pacific Ocean. In contrast, some studies have reported that phytoplankton biomass is controlled from above by 
zooplankton grazing in the region (Frost 1987, Parsons \& Lalli 1988, Miller et al. 1991). Cooney (1988) showed that predation by pink salmon may have a measurable impact on ocean macrozooplankton stock in the Gulf of Alaska. Odate (1994) showed the possibility of the predation effect on macrozooplankton biomass by Pacific saury, which is a planktivore in the subarctic North Pacific. However, little is known about the trophic relations among phytoplankton, zooplankton and fish in the subarctic North Pacific Ocean.

In this paper we elucidate the year-to-year variations in biomass of phyto- and macrozooplankton and abundance of pink salmon in the central subarctic North Pacific from 1985 to 1994, and discuss the trophic relations among them.

The salmon is a pelagic fish and an important predator in the subarctic North Pacific Ocean. The life span of the pink salmon is $2 \mathrm{yr}$ and $2 \mathrm{yr}$ old pink salmon (adults) feed on macrozooplankton and small-sized nekton (Takagi et al. 1981). Catch Per Unit Effort (CPUE), which is a fish abundance indicator, of pink salmon contributes significantly to the total CPUE of all salmon in the subarctic North Pacific and the Bering Sea, and the CPUE of pink salmon repeats a pattern of increase then decrease year after year (Ishida 1995). Thus, if macrozooplankton biomass is controlled by consumption by pink salmon, that biomass will also vary yearly. Furthermore, the indirect effects of feeding by pink salmon may extend to the phytoplankton biomass. For these reasons, we selected pink salmon for our study

\section{MATERIALS AND METHODS}

Our study area corresponds to the North Pacific Ocean north of the Transition Domain defined by Favorite et al. (1976).

Surface chlorophyll a (chl a) concentrations cited here are from Shiomoto \& Maita (1990) for 1985, N. Shiga et al. (unpubl.) for 1986 and 1987, Y. Maita et al. (unpubl.) for 1988 and 1989, and K. Matsunaga et al. (unpubl.) for 1990. The 1985 to $1990 \mathrm{chl}$ a data were obtained between $45^{\circ} 30^{\prime} \mathrm{N}$ and $51^{\circ} 30^{\prime} \mathrm{N}, 168^{\circ} \mathrm{E}$ and $170^{\circ} \mathrm{W}$ from June to August (Fig. 1). The data for 1991 to 1994 were obtained during cruises of the RV 'Wakatake Maru' belonging to the Education Bureau of Hokkaido between $46^{\circ} 30^{\prime} \mathrm{N}$ and $51^{\circ} 30^{\prime} \mathrm{N}$ along $179^{\circ} 30^{\prime} \mathrm{W}$ in June and July (Fig 1). All of the stations belonged to the North Pacific Subarctic Water defined by Sverdrup et al. (1946). Surface chl a concentrations were determined for 1985 to 1994 . Chl a concentrations were also determined at 0,10,20,30,50,75 and $100 \mathrm{~m}$ for 1986 to 1989 and in 1993 and 1994, and at 0, 2, 5, 10, 25, 50 and $100 \mathrm{~m}$ in 1990 . Whatman GF/F filters were

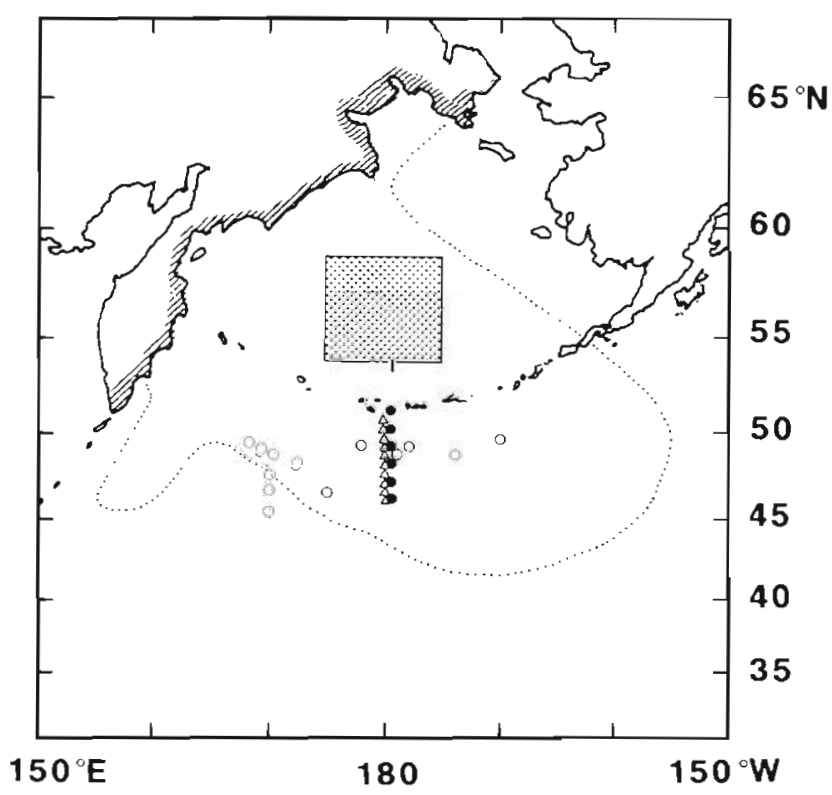

Fig. 1. Location of sampling stations: $(-\mathrm{chl} a$ and wet weight data from RV 'Wakatake Maru' cruises from 1991 to 1994; (O) chl a data for 1985 to 1990 from Shiomoto \& Maita (1990), Shiga ef al. (unpubl.), Maita et al. (unpubl.) and Matsunaga et al. (unpubl.); ( $\Delta$ ) wet welght data from Hokkaido University (1986-1991) for 1985 to 1990. All wet weight data collected by NORPAC net. Stations were located north of the Transition Domain defined by Favorite et al. (1976). Also shown are the coastal ongin (hatching area) and area of ocean migration of pink salmon originating in East Kamchatka and northward to Anadyr Bay (habitat area enclosed by dotted line) (after Takagi et al. 1981). (f.) Fishing operations for calculation of Catch Per Unit Effort (CPUE) of pink salmon carried out in the central Bering Sea (Fisheries Agency of Japan 1986-1995)

used for collecting the samples for chl a determination in all studies except for Shiomoto \& Maita (1990) for 1985 and Shiga et al. (unpubl.) for 1986; a Whatman GF/C filter was used in those 2 studies. Chl a concentration was determined by fluorometry after extraction by $90 \%$ acetone according to Parsons et al. (1984a). We plotted the surface chl a concentration $\left(\mathrm{mg} \mathrm{m}^{-3}\right)$ against the chl a biomass ( $\mathrm{mg} \mathrm{m}^{-2}$ ) integrated from the surface to a $100 \mathrm{~m}$ depth. A good linear relation was found between the surface chl a concentration and the integrated chl a biomass $(r=0.739, n=30, p<0.001)$. This result shows that surface variation in chl a concentration probably represents the variation in the whole phytoplankton biomass within a water column. In addition, seawater samples from 1992 and 1993 were used to determine the size-fractionated chl a concentrations: $>10,2-10$ and $<2 \mu \mathrm{m}$ fractions. The samples were filtered separately through Nuclepore filters with pore sizes of 10 and $2 \mu \mathrm{m}$ and a Whatman GF/F filter.

Phytoplankton productivity was measured from 1991 to 1993 at the surface by simulated in situ methods 
using a ${ }^{13} \mathrm{C}$ technique (Hama et al. 1983) during the cruises of the RV 'Wakatake Maru' in June and July (Fig. 1). Seawater samples were collected by plastic bucket around noon, and dispensed into $1 \mathrm{l}$ polycarbonate bottles immediately after sieving through a $200 \mu \mathrm{m}$ mesh screen to remove large zooplankton. The ${ }^{13} \mathrm{C}$ enrichment was about $10 \%$ of the total inorganic carbon in the ambient water Incubation experiments were conducted under simulated surface conditions: bottles were cooled with near-surface seawater for about 2 or $3 \mathrm{~h}$. Incubation was terminated by filtration onto precombusted $47 \mathrm{~mm}$ Whatman GF/F filters $\left(450^{\circ} \mathrm{C}\right.$ for $\left.4 \mathrm{~h}\right)$. Filters were then rinsed with filtered seawater, and filter papers were immediately frozen and preserved for later isotope analysis. After the papers were treated with $\mathrm{HCl}$ fumes for $4 \mathrm{~h}$ to remove inorganic carbon, they were completely dried in a vacuum desiccator. The isotopic ratio ${ }^{13} \mathrm{C}:{ }^{12} \mathrm{C}$ was determined using an infrared absorption analyzer, JASCO EX-130S (Japan Spectroscopic Inc., Tokyo). Particulate organic carbon was determined simultaneously.

Wet weight data, except salp and jellyfish, obtained from North Pacific standard net (NORPAC) operations $(0$ to $150 \mathrm{~m})$ were used as an index of macrozooplankton biomass. The mesh size of the net was $330 \mu \mathrm{m}$ Data cited here for 1985 to 1990 are from Hokkaido University (1986-1991) and were obtained between $45^{\circ} 30^{\prime} \mathrm{N}$ and $50^{\circ} \mathrm{N}$ along $180^{\circ}$ in June and July (Fig. 1) The data from 1991 to 1994 were obtained during the cruises of the RV 'Wakatake Maru' between $46^{\circ} 30^{\prime} \mathrm{N}$ and $51^{\circ} 30^{\prime} \mathrm{N}$ along $179^{\circ} 30^{\prime} \mathrm{W}$ in June and July (Fig. 1) (Tadokoro et al. 1995). Samples collected from 1991 to 1994 were sorted into taxonomic categories: euphausiids, copepods, amphipods, pteropods, appendicularians, chaetognaths, fish larvae, squids, ostracods, mysids, decapods and polychaetes; and their wet weight was totalled.

We used the CPUE of pink salmon collected by nonselective research gillnet (Takagai 1975) in the central Bering Sea from June to August (Fisheries Agency of Japan 1986-1995) to show the year-to-year variation in pink salmon abundance in the subarctic North Pacific (Fig 1). Adult pink salmon migrating in our study field (the central subarctic North Pacific) mostly originate in east Kamchatka and in contiguous coastal areas northward to Anadyr Bay, and the pink salmon migrate from. the subarctic North Pacific to the central Bering Sea in the summer of their second year (Takagi et al. 1981) (Fig. 1). Hence, the CPUE in the central Bering Sea represents the yearly variation in pink salmon abundance in our study area.

Surface temperatures and nitrogenous nutrient (nitrite + nitrate) concentrations for 1985 to 1990 were obtained from Hokkaido University (1986-1991), and those for 1991 to 1994 were measured during the cruises of the RV 'Wakatake Maru' (see Fig. 1). The Hokkaido University data were obtained between $45^{\circ} 30^{\prime} \mathrm{N}$ and $51^{\circ} \mathrm{N}$ along $180^{\circ}$ and the data from the 'Wakatake Maru' cruises between $46^{\circ} 30^{\prime} \mathrm{N}$ and $51^{\circ} 30^{\prime} \mathrm{N}$ along $179^{\circ} 30^{\prime} \mathrm{W}$ in June and July. In the 'Wakatake Maru' cruises, temperatures were measured with a thermometer, and the nutrient concentrations were determined according to Parsons et al. (1984a) or by Bran and Luebbe Traacs 800 after frozen storage

\section{RESULTS}

Year-to-year variation in surface chl a concentration is shown in Fig. 2a. Values were variable within each year but the mean value in each year had a tendency as follows. Mean values were nearly constant from 1985 to 1990 (Fig. 2b) although the value was somewhat higher in 1987 In contrast, the value varied yearly from 1990 to 1994, with higher values observed in the odd-numbered years (1991 and 1993) and lower values in the even-numbered years (1990, 1992 and 1994). Mean value \pm standard deviation (SD) was calculated to be $0.88 \pm 0.45 \mathrm{mg} \mathrm{m}^{-3}(\mathrm{n}=12)$ in the oddnumbered years after 1990 and $0.39 \pm 0.20 \mathrm{mg} \mathrm{m}^{-3}(\mathrm{n}=$ 16) for the even-numbered years after 1989. The mean value for the odd-numbered years was significantly different ( $t$-test or Cochran-Cox test, $p<0.001$ ) to that for the even-numbered years, with the former being about twice the latter. The mean \pm SD before 1990 was calculated to be $0.43 \pm 0.20 \mathrm{mg} \mathrm{m}^{-3}(\mathrm{n}=22)$. The mean value was not significantly different from that of the even-numbered years after 1989 ( $p>0.10)$, but significantiy different from that of the odd-numbered years after 1990 ( $p<0.001)$. Chl a concentrations before 1990 were low, being equal to those of the even-numbered years after 1989 .

The percentage contribution of the $>10 \mu \mathrm{m}$ fraction to total chl a concentration had a tendency to be somewhat smaller in 1992 (mean $=22 \%$ ) than in 1993 (mean $=36 \%$ ), and an opposite trend was found in the $<2 \mu \mathrm{m}$ fraction $($ mean $=59 \%$ in 1992 ; mean $=46 \%$ in 1993) (Table 1). No significant difference, however, was found between the 2 years

Mean phytoplankton production ( $\mathrm{mg} \mathrm{C} \mathrm{m}^{-3} \mathrm{~h}^{-1}$ ) in the even-numbered year 1992 was not significantly different from that in the odd-numbered years 1991 and 1993 (Table 2). In contrast, mean productivity (production per unit chl a) was significantly higher in 1992 than in 1991 and $1993(p<0.002)$ (Table 2).

Year-to-year variation in wet weight collected by NORPAC net is shown in Fig. 2c. The values were variable within each year but the mean value in each year had a tendency as follows. Mean values were nearly 

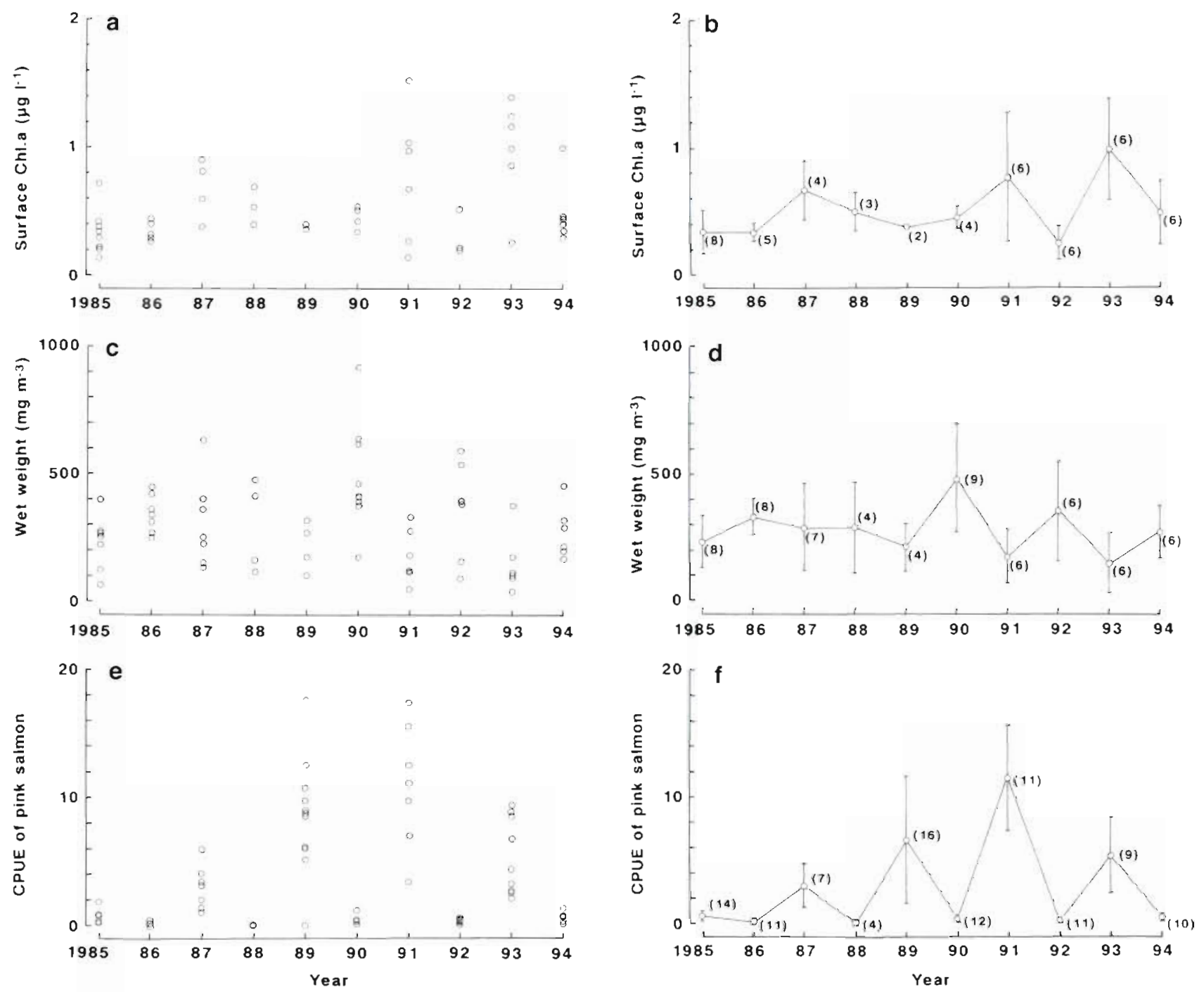

Fig. 2. (a) Measured surface chl a concentrations and (b) mean yearly surface chl a concentration; (c) wet weight of macrozooplankton samples collected by NORPAC net and (d) mean yearly wet weight of macrozooplankton; and (e) CPUE of pink salmon and (f) trend in the mean value for each year. Number of samples shown in parentheses; error bars show $\pm \mathrm{SD}\left(\sigma_{\mathrm{n}-1}\right)$

constant from 1985 to 1989 (Fig. 2d). In contrast, the value varied yearly from 1989 to 1994, with lower values observed in the odd-numbered years $(1989,1991$ and 1993) and higher values in the even-numbered

Table 1. Mean $\pm \mathrm{SD}\left(\sigma_{\mathrm{n}-1}\right)$ of percentage contributions of $<2$, $2-10$ and $>10 \mu \mathrm{m}$ fractions to total chl a concentration in the even-numbered year 1992 and odd-numbered year 1993 in RV 'Wakatake Maru' cruises between $46^{\circ} 30^{\prime} \mathrm{N}$ and $51^{\circ} 30^{\prime} \mathrm{N}$ along $179^{\circ} 30^{\prime} \mathrm{W}$. Number of samples shown in parentheses

\begin{tabular}{|cccc|}
\hline Year & $<2 \mu \mathrm{m}$ & $2-10 \mu \mathrm{m}$ & $>10 \mu \mathrm{m}$ \\
\hline 1992 & $59 \pm 14(6)$ & $19 \pm 18(6)$ & $22 \pm 23(6)$ \\
1993 & $46 \pm 10(6)$ & $18 \pm 5(6)$ & $36 \pm 10(6)$ \\
\hline
\end{tabular}

years (1990, 1992 and 1994), a pattern which was opposite to that of $\mathrm{chl}$ a concentration. Mean value \pm $\mathrm{SD}$ was calculated to be $177 \pm 104 \mathrm{mg} \mathrm{m}^{-3}(\mathrm{n}=16)$ for the odd-numbered years after 1988 and $390 \pm 197 \mathrm{mg}$ $m^{-3}(n=21)$ for the even-numbered years after 1989. The mean value for the odd-numbered years was significantly different $(p<0.001)$ to that for the evennumbered years, with the former being about half the latter Mean \pm SD was calculated to be $286 \pm 128 \mathrm{mg}$ $\mathrm{m}^{-3}(\mathrm{n}=27)$ before 1989 . The mean value for 1985 to 1988 was between the mean values for the even-and odd-numbered years after 1988, and significantly different from the mean value of the even-numbered years $(p<0.05)$ and of the odd-numbered years after 1988 ( $p<0.01$ ). The difference between the mean val- 
ues before 1989 and in the even-numbered years after 1989 was, however, only marginally significant. Moreover, the mean value before 1989 was not significantly different from the mean value in the even-numbered years after 1989, except for the highest value in 1990 ( $p>0.05$ ). Consequently, the wet weight before 1989 may have been rather high, a pattern which is contrary to that of chl a concentration.

Mean $\pm \mathrm{SD}$ of percentage contribution of copepods to total wet weight in each year from 1991 to 1994 is shown in Table 3 . The mean percentage contributions of copepods in each year ranged from 68 to $82 \%$. Mean $\pm \mathrm{SD}$ for all data was calculated to be $76 \pm 15 \%$.

The year-to-year variation in pink salmon CPUE is shown in Fig. 2e. The values were variable within each year but the mean value in each year had a tendency as follows. Mean CPUE was high in the odd-numbered years and low in the even-numbered years throughout


Fig. 3. Relationships between (a) mean surface chl a concentration and mean wet weight of macrozooplankton in each year, and (b) mean wet weight of macrozooplankton and mean CPUE of pink salmon in each year. Numbers indicate year
Table 2. Mean $\pm \mathrm{SD}\left(\sigma_{\mathrm{n}-1}\right)$ of production and production per unit chl a (productivity) at the surface in the odd-numbered years 1991 and 1993 and the even-numbered year 1992 in RV 'Wakatake Maru' cruises between $46^{\circ} 30^{\prime} \mathrm{N}$ and $51^{\circ} 30^{\prime} \mathrm{N}$ along $179^{\circ} 30^{\prime} \mathrm{W} . \mathrm{n}$ is the number of samples

\begin{tabular}{|lcc|}
\hline & $\begin{array}{c}1991 \text { and } 1993 \\
(\mathrm{n}=11)\end{array}$ & $\begin{array}{c}1992 \\
(\mathrm{n}=6)\end{array}$ \\
\hline $\begin{array}{l}\text { Production } \\
\left(\mathrm{mg} \mathrm{C} \mathrm{m} \mathrm{C}^{-3} \mathrm{~h}^{-1}\right)\end{array}$ & $1.71 \pm 1.07$ & $1.07 \pm 0.42$ \\
$\begin{array}{l}\text { Production/chl a } \\
\left(\mathrm{mg} \mathrm{C} \mathrm{mg} \mathrm{chl} \mathrm{a}^{-1} \mathrm{~h}^{-1}\right)\end{array}$ & $2.12 \pm 1.15$ & $4.40 \pm 1.24$ \\
\hline
\end{tabular}

Table 3. Mean \pm SD $\left(\sigma_{n-1}\right)$ of percentage contribution of copepods to wet weight of macrozooplankton collected during RV 'Wakatake Maru' cruises between $46^{\circ} 30^{\prime} \mathrm{N}$ and $51^{\circ} 30^{\prime} \mathrm{N}$ along $179^{\circ} 30^{\prime} \mathrm{W}$ from 1991 to 1994 . $\mathrm{n}$ is number of samples for each year

\begin{tabular}{|lcccc|}
\hline & 1991 & $\begin{array}{c}1992 \\
(\mathrm{n}=6)\end{array}$ & 1993 & 1994 \\
\hline $\begin{array}{l}\text { Percentage contribution } \\
\text { by copepods }\end{array}$ & $79 \pm 11$ & $82 \pm 7$ & $73 \pm 14$ & $68 \pm 23$ \\
\hline
\end{tabular}

the 10 уг (1985-1994) (Fig. 2f). However, the values in the odd-numbered years after 1988 were remarkably higher than those before 1988; the fluctuation before 1988 was small and that after 1988 was large. The pattern of yearly variation in the mean CPUE after 1988 was similar to that in phytoplankton biomass and contrary to that in macrozooplankton biomass.

The relationships between surface chl a and wet weight, and between wet weight and pink salmon CPUE are shown in Fig. 3. Negative trends were found in both relations but linear correlations were not significant $(p>0.05)$. The linear correlations, however, were significant if the value for 1990 was excluded from the calculation $(p<0.05)$. Moreover, the Spearman rank test correlation was not significant in the relationship between chl a concentration and wet weight ( $p>0.05$ ), but was significant if the 1990 value was excluded from the calculation $(p<0.05)$. In contrast, the test correlation was significant in the relationship between wet weight and CPUE $(p<0.05)$.

Surface temperatures and nitrite+nitrate concentrations are shown in Fig. 4. Most temperatures were within the range of 5 to $7^{\circ} \mathrm{C}$, and temperatures were roughly constant throughout the $10 \mathrm{yr}$. Surface nitrogenous nutrient concentrations were variable in each year, but most values during the 10 yr were 


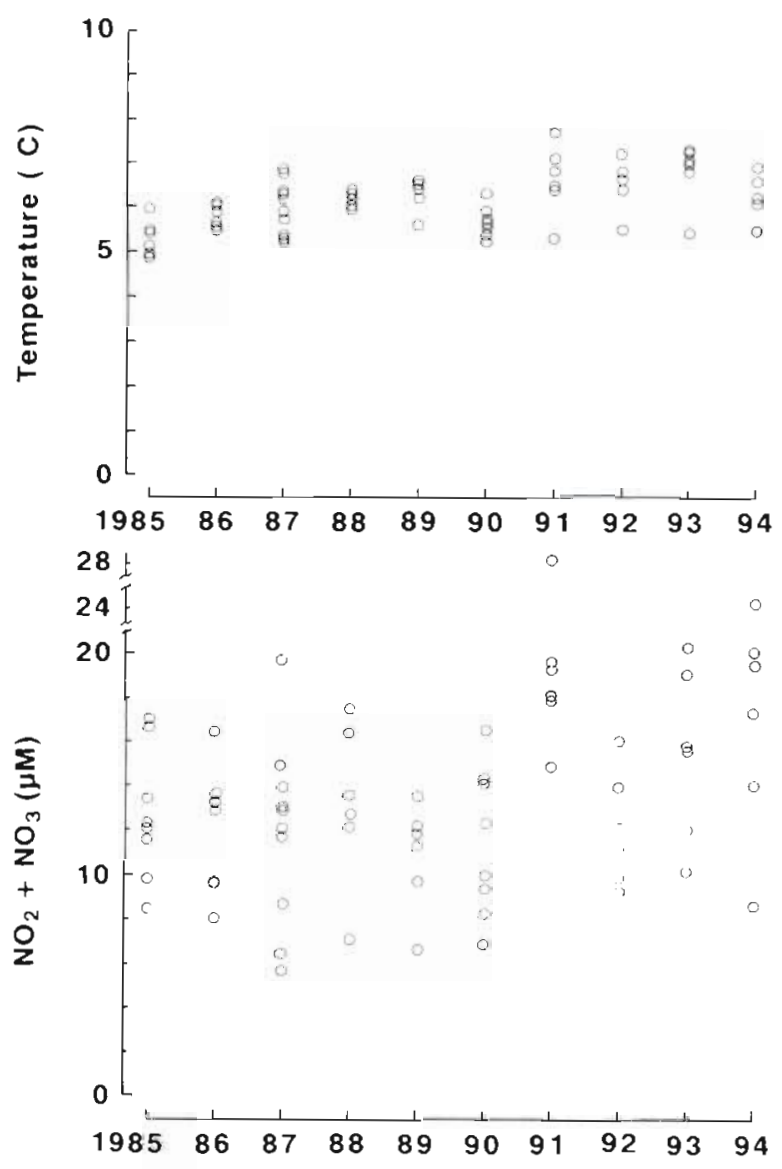

Fig. 4. Observations of temperature and nitrite+nitrate concentration at the surface. Data for 1985 to 1990 were collected on. RV 'Oshoro Maru' cruises between $45^{\circ} 30^{\prime} \mathrm{N}$ and $51^{\circ} 30^{\prime} \mathrm{N}$ along $180^{\circ}$ (Hokkaido University 1986-1991) and the data for 1991 to 1994 on RV 'Wakatake Maru' cruises between $46^{\circ} 30^{\prime} \mathrm{N}$ and $51^{\circ} 30^{\prime} \mathrm{N}$ along $179^{\circ} 30^{\prime} \mathrm{W}$

within the range of 8 to $20 \mu \mathrm{M}$. Nitrogenous nutrient was abundant in every year and probably not a limiting factor in phytoplankton productivity.

\section{Balance between phytoplankton and macrozooplankton biomass after 1989}

The difference between phytoplankton production and loss due to grazing, respiration and sinking etc. is phytoplankton biomass, i.e. chl a concentration. The difference between chl a concentration in the oddnumbered and even-numbered years $(\Delta \mathrm{chl} a)$ is described as follows:

$$
\Delta c h l a=\left(P_{O}-L_{O}\right)-\left(P_{E}-L_{E}\right)
$$

where $P_{O}$ and $P_{\mathrm{E}}$ are phytoplankton production in the odd- and even-numbered years, respectively, and $L_{O}$ and $L_{E}$ are loss in the odd-and even-numbered years, respectively. Phytoplankton production in the odd and even-numbered years is assumed to be equal. This assumption is based on the finding that surface production (mg C m${ }^{-3} \mathrm{~h}^{-1}$ ) did not significantly differ between the odd-and even-numbered years (Table 1) Loss except by grazing in the odd- and even-num. bered years is also assumed to be equal. Respiration is approximately $10 \%$ of maximum production (Parsons et al. 1984b). The assumption of constant respiration is supported by our finding showing nearly constant surface production. As a result, Eq. (1) is simplified as follows:

$$
\Delta \text { Chl } a=G_{E}-G_{O}
$$

where $G_{\mathrm{E}}$ and $G_{\mathrm{O}}$ are grazing rate in the even-and odd-numbered years, respectively. The grazing rate is described as follows:

$$
G=g N
$$

where $g$ is the grazing rate per individual animal and $N$ is the number of animals. $g$ in the odd-and evennumbered years is assumed to be equal. This assumption is based on the finding that temperature, which has a considerable influence on zooplankton productivity, and phytoplankton production, as a potential food source for zooplankton, were not significantly different between the odd- and even-numbered years (Fig. 4, Table 2). As a result, Eq. (2) is described as follows:

$$
\Delta \mathrm{chl} a=g\left(N_{\mathrm{E}}-N_{\mathrm{O}}\right)
$$

where $N_{E}$ and $N_{O}$ are the number of animals in the even- and odd-numbered years, respectively.

The mean surface chl a concentration was $0.88 \mathrm{mg}$ $\mathrm{m}^{-3}$ in the odd-numbered years after 1990 (1991 and 1993) and $0.39 \mathrm{mg} \mathrm{m}^{-3}$ in the even-numbered years after 1989 (1990, 1992 and 1994). The difference between chl a concentration in the odd-and evennumbered years is $0.49 \mathrm{mg} \mathrm{m}^{-3}$. According to Landry et al. (1993), the grazing by Neocalanus plumchrus (the fifth copepodite starge), which is an important grazer in the subarctic Pacific, has an effect on phytoplankton larger than $8 \mu \mathrm{m}$ cell size. The phytoplankton of the $>10 \mu \mathrm{m}$ fraction is considered to be the object of grazing by copepods, i.e. macrozooplankton, in this study. The phytoplankton of the $>10 \mu \mathrm{m}$. fraction accounted for on average $22 \%$ of total chl $a$ in the even-numbered year 1992 and $36 \%$ in the odd-numbered year 1993 (Table 1) Using the mean percentage contributions of the $>10 \mu \mathrm{m}$ fraction, mean chl a concentration of the $>10 \mu \mathrm{m}$ fraction was $0.09 \mathrm{mg} \mathrm{m}^{-3}$ in the even-numbered years after 1989 and $0.32 \mathrm{mg} \mathrm{m}^{-3}$ in the oddnumbered years after 1990. The difference between both values, i.e. $\Delta c h l$ a attributed to copepod grazing, is $0.23 \mathrm{mg} \mathrm{m}^{-3}$. The difference $\left(0.23 \mathrm{mg} \mathrm{m}^{-3}\right)$ accounts for 
$47 \%$ of the total reduced $\mathrm{chl} a\left(0.49 \mathrm{mg} \mathrm{m}^{-3}\right)$. The carbon:chl a weight ratio changes remarkably, but the ratio is generally in the range of 10 to 100 for active phytoplankton (see Odate et al. 1993 and references therein). As a result, $0.23 \mathrm{mg} \mathrm{m}^{-3}$ is converted to 2.3 to $23 \mathrm{mg} \mathrm{C} \mathrm{m} \mathrm{m}^{-3}$

The grazing rate for individual animals, $g$ (mg $\mathrm{C}$ animal $\left.{ }^{-1} \mathrm{~h}^{-1}\right)$, is estimated using the formula devised by Ikeda \& Motoda (1978):

$$
g=2.5 R
$$

where $R$ is respiration rate. $R$ was calculated based on the mean body dry weight $(0.45 \mathrm{mg}$, see below), and the mean surface water temperature $\left(6.3^{\circ} \mathrm{C}\right)$ was calculated from the data for 1990 to 1994, using Ikeda's (1974) formula:

$$
\begin{aligned}
\log R= & (-0.01089 T+0.8918) \log W \\
& +(0.02438 T-0.1838)
\end{aligned}
$$

where $W$ is dry weight and $T$ is water temperature. $R$ is generally calculated as a unit in $\mu_{l} \mathrm{O}_{2}$ animal $^{-1} \mathrm{~h}^{-1}$, and the conversion to units in $\mathrm{mg} \mathrm{C}$ animal ${ }^{-1} \mathrm{~h}^{-1}$ is made by the following equation (Parsons et al. 1984b):

$$
\begin{aligned}
\mathrm{mg} \mathrm{C}_{\text {animal }} \mathrm{h}^{-1} \mathrm{~h}^{-1}= & \mu \mathrm{l} \mathrm{O}_{2} \text { animal }^{-1} \mathrm{~h}^{-1} \\
& \times 12 / 22.4 \times \mathrm{RQ} \times 10^{-3}
\end{aligned}
$$

where RQ is the respiration quotient. We adopted 0.8 as $R Q$ (protein metabolism). $R$ was calculated to be $2.07 \times 10^{-4} \mathrm{mg} \mathrm{C}$ animal $^{-1} \mathrm{~h}^{-1}$ and then $g$ was estimated to be $5.18 \times 10^{-4} \mathrm{mg} \mathrm{C}$ animal $^{-1} \mathrm{~h}^{-1}$

Copepods (the fifth copepodite stage) live in surface layers and graze phytoplankton from April to June in the subarctic region (LeBrasseur 1972, Fulton 1973 , Miller 1984). Phytoplankton bloom was observed in May and somewhat later in the central subarctic North Pacific (Anderson \& Munson 1972). Copepod grazing probably has a serious influence on phytoplankton biomass after bloom. Copepods comprised most of the macrozooplankton biomass (Table 3). Hence, we assumed that phytoplankton biomass suffers an intense grazing effect from macrozooplankton in June. Moreover, assuming that copepods graze phytoplankton without interruption, the grazing amount by individual copepods in June (over 30 d) was estimated to be $0.37 \mathrm{mg} \mathrm{C}$.

The mean wet weight of macrozooplankton was calculated to be $165 \mathrm{mg} \mathrm{m}^{-3}$ in the odd-numbered years after 1990 (1991 and 1993) and $390 \mathrm{mg} \mathrm{m}^{-3}$ in the even-numbered years after 1989 (1990, 1992 and 1994). Copepods comprised most of the wet weight, accounting for $76 \%$ as an average in the 1991 to 1994 period. Dry weight is assumed to be $15 \%$ of wet weight for copepods, because the range of dry-perwet weight is 10 to $20 \%$ for the species (Parsons et al. $1984 \mathrm{~b})$. Hence, the dry weight for copepods was cal- culated to be $44 \mathrm{mg} \mathrm{m}^{-3}\left(390 \mathrm{mg} \mathrm{m}^{-3} \times 0.76 \times 0.15\right)$ in the even-numbered years and $19 \mathrm{mg} \mathrm{m}^{-3}\left(165 \mathrm{mg} \mathrm{m}^{-3}\right.$ $\times 0.76 \times 0.15)$ in the odd-numbered years. Neoculanus spp. (the fifth copepodite stage) dominate copepods in the subarctic Pacific Ocean in spring and early summer (e.g. Parsons \& Lalli 1988, Mackas et al. 1993). Their dry weight per individual ranges mostly from 0.1 to $0.25 \mathrm{mg}$ in May and from 0.3 to $0.6 \mathrm{mg}$ in June, according to Miller (1993). Using the mean value (0.45 $\mathrm{mg}$ ), the mean number of copepods within the water column above $150 \mathrm{~m}$ in June (our sampling period) was calculated to be 98 ind $\mathrm{m}^{-3}$ (44 $\mathrm{mg}$ $\mathrm{m}^{-3} / 0.45 \mathrm{mg}$ ind ${ }^{-1}$ ) in the odd-numbered years and 42 ind. $\mathrm{m}^{-3}\left(19 \mathrm{mg} \mathrm{m}^{-3} / 0.45 \mathrm{mg}^{-1} \mathrm{md}^{-1}\right)$ in the evennumbered years. The numbers of individuals $\mathrm{m}^{-3}$ obtained in our study were within the range of the number of individuals $\mathrm{m}^{-3}$ observed in summer by Dagg (1993). The difference between the number of animals in the even- and odd-numbered years $\left(N_{\mathrm{E}}-\right.$ $N_{0}$ ) was 56 ind $\mathrm{m}^{-3}$ Consequently, the difference in grazing amount by copepods between the even- and odd-numbered years, i.e. the right term in Eq. (4), was

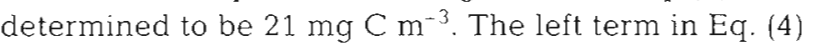
was estimated to be 2.3 to $23 \mathrm{mg} \mathrm{C} \mathrm{m}^{-3}$ The values in the left and right terms in Eq. (4) are almost equal.

\section{DISCUSSION}

Remarkable year-to-year variation was found in phytoplankton biomass after 1989 (Fig. 2a, b). The biomass was high in the odd-numbered years (1991 and 1993) and low in the even-numbered years (1990, 1992 and 1993). It is difficult to attribute the variation to an influence of other waters, because all of the stations belonged to one water mass, i.e. the North Pacific Subarctic Water temperature was nearly constant, and nitrate concentration was roughly constant during the $10 \mathrm{yr}$ (Fig. 4). A phytoplankton bloom has been observed in May and June in the central subarctic North Pacific (Anderson \& Munson 1972), and the high and low biomass may consequently reflect bloom and nonbloom, respectively. Surface nutrient concentrations decreased after the bloom (Anderson \& Munson 1972). Accordingly, if the year-to-year variation of phytoplankton biomass were a reflection of bloom and nonbloom, surface-nutrient concentrations would differ between the odd-numbered and even-numbered years after 1989. As an example, however, the mean concentrations of nitrogenous nutrient in the odd-numbered years 1991 and 1993 and even-numbered years 1992 and 1993 did not significantly differ ( $t$-test, $p>0.1$ ). It is thus hard to conceive that the variation is a reflection of bloom and nonbloom. Moreover, in contrast to 
the year-to-year variation, there was no significant difference between surface temperature in the oddand even-numbered years after 1990, and the nitrogenous nutrient concentrations were high in every year (Fig. 4). Phytoplankton productivity (mg C mg chl $a^{-1} h^{-1}$ ) was higher in the even- than in the odd-numbered years, a pattern which was opposite to that of phytoplankton biomass (Table 2). These results imply that the year-to-year variation in phytoplankton biomass after 1989 was not regulated by the physical or chemical environmental factors, nor by its own productivity. An inverse relation tendency was found between phytoplankton and macrozooplankton biomass (Fig, 3a). The biomass of copepods that graze on phytoplankton controlled the year-to-year variation in macrozooplankton biomass (Table 3). Our trial estimate showed an equilibrium between the grazing amount of copepods and the reduced biomass of large-sized phytoplankton $(>10 \mu \mathrm{m})$ after 1989 (see 'Results'). The large-sized phytoplankton contributed about half of the changed total phytoplankton biomass between the even- and odd-numbered years after 1989 (see 'Results'), and thereby the copepod grazing amount accounted for half of the reduced phytoplankton biomass. The remaining approximate half of the variation in phytoplankton biomass consisted of small-sized phytoplankton of the $<10 \mu \mathrm{m}$ size. Small-sized phytoplankton generally suffer microzooplankton grazing impact (e.g. Stockner \& Antia 1986, Capriulo 1990). Consequently, the remaining half of the reduced biomass should be equal to the microzooplankton grazing amount. Although we have no data to examine this equivalence, the microzooplankton grazing amount seems to account for 50 to $200 \%$ of phytoplankton production (Booth et al. 1993) and be several times greater than the macrozooplankton grazing amount (Booth et al. 1993, Dagg 1993) in the subarctic North Pacific in spring and summer We thus suspect that the remaining half of the reduced total phytoplankton biomass is attributable to the grazing amount of microzooplankton, although this is an important problem for future study. Based on the point mentioned above, we strongly suggest that the year-to-year variation in phytoplankton biomass after 1990 was controlled by zooplankton consumption.

Phytoplankton productivity was high in the evennumbered years in which phytoplankton biomass was low, and low in the odd-numbered years in which its biomass was high (Table 2). Surface temperature and nitrate concentration were roughly constant throughout the 10 yr (Fig 4). Hence, phytoplankton may recover from a reduction in biomass caused by zooplankton grazing to previous levels by means of increasing productivity; namely, phytoplankton may have a capacity to compensate for losses in biomass. On the other hand, the percentrage contribution by phytoplankton of $<2 \mu \mathrm{m}$ size to biomass had a tendency to be higher in 1992 than in 1993 (Table 1). It seems that small-sized phytoplankton has higher productivity than large-sized phytoplankton (e.g. Malone 1980). The productivity difference between odd-and even-numbered years may be due to differences in the size compasition of phytoplankton assemblages. The reason for variations in yearly phytoplankton productivity in spite of constant temperature and nitrogenous nutrient concentration should be studied in the future.

Remarkable year-to-year variation was found in macrozooplankton biomass after 1988 (Fig. 2C, d). Biomass was high in the even-numbered years (1990, 1992 and 1994) and low in the odd-numbered years $(1989,1991$ and 1993). It is unlikely that other waters influenced the variation (see above). Copepods (the fifth copepodite stage) that predominated in the macrozooplankton biomass (Table 3) inhabit the surface layers during April to June and then migrate to deeper layers (LeBrasseur 1972, Fulton 1973, Miller 1984). The vertical migration influences the macrozooplankton biomass in the surface layers, and thereby may affect the variation. Copepod abundance in the surface layers declines rapidly during late summer and early autumn (Miller 1984). Macrozooplankton biomass data used in this paper were obtained in midsummer (June and July). It is thus hard to conceive that there was an influence of vertical migration on the variation. Moreover, mean phytoplankton production ( $\mathrm{mg} \mathrm{C} \mathrm{m} \mathrm{m}^{-3} \mathrm{~h}^{-1}$ ) in the even-numbered year 1992 was not significantly different from that in the odd-numbered years 1991 and 1993 (Table 2). This means that the potential food source for macrozooplankton was roughly constant during those years. Temperature, which has a significant influence on macrozooplankton productivity, was roughly constant throughout the $10 \mathrm{yr}$ (Fig. 4). These facts imply that macrozooplankton productivity itself did not change remarkably from 1989 to 1994. Consequently, the year-to-year variation in macrozooplankton biomass was likely to be controlled from above by consumers. Copepods comprised most of the macrozooplankton biomass (Table 3). Primary carnivores such as amphipods and chaetognaths are in a higher trophic position than copepods (LeBrasseur 1972). The carnivore biomass showed the same year-to-year variation as that of the copepods in 1991 to 1994 (Fig. 5). This means that the primary carnivores play only a small part in controlling the copepod biomass. Hence, we suggest that the copepod biomass is influenced by higher trophic levels. Copepods are important food for pink salmon during spring and summer (LeBrasseur 


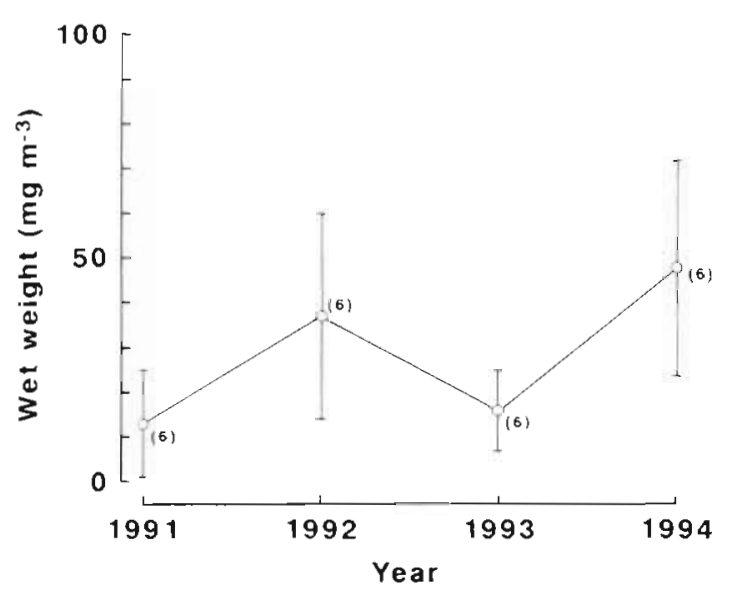

Fig. 5. Year-to-year variation in mean wet weight of carnivorous macrozooplankton. Wet weight is the sum of wet weight of amphipods and chaetognaths. Number of samples is shown in parentheses; error bars show $\pm \mathrm{SD}\left(\sigma_{n-1}\right)$. Data cited is from Tadokoro et al. (1995)

1972), especially in a rich year (high CPUE) (Ito 1964). A significant negative relation was found between the macrozooplankton biomass and the CPUE of pink salmon (Fig. 3b). We suggest that pink salmon was one of the consumers influencing the yearly variation in macrozooplankton biomass after 1989

We think, based on the discussion above, that the feeding effect from pink salmon controlled, directly or indirectly, the biomass of zoo-and phytoplankton after 1989. On the other hand, before 1988 pink salmon abundance was not so variable from year to year and remained low (Fig. 2e, f). This implies that consumption by pink salmon had little influence on macrozooplankton biomass before 1989, thereby allowing macrozooplankton biomass to remain at a rather high level and phytoplankton biomass to remain low accordingly (Fig. 2a, c).

We have discussed the trophic relations among phyto-and macrozooplankton and pink salmon using summer data. Phytoplankton biomass probably suffers an intense grazing impact from macrozooplankton after a phytoplankton bloom, i.e. in spring and early summer, as mentioned above. Macrozooplankton biomass probably suffers a predation impact from pink salmon in spring and early summer because copepods (the fifth copepodite stage), which control the zooplankton biomass, live in the surface layer from April to June (LeBrasseur 1972, Fulton 1973) when adult pink salmon migrate to our study area (Takagi et al. 1981). Considering the above, we came to the conclusion that the year-to-year variation in pink salmon abundance plays a large part in controlling summer biomass of macrozoo- and phytoplankton in the central subarctic North Pacific.
Acknowledgements. We are very grateful to Profs. Y Maita and K. Matsunaga, and Assistant Profs. N. Shiga and M. Yanada, Faculty of Fisheries, Hokkaido University, for kindly permitting the use of their unpublıshed results. We thank the captain and crew of the RV 'Wakatake Maru' for collecting samples. We also extend our appreciation to Prof. A. Taniguchi, Tohoku Unuversity, for his cntıcal and helpful comments on the manuscript. Finally, we express our gratitude to Mr J. M. Thompson for correcting the manuscript.

\section{LITERATURE CITED}

Anderson GC, Munson RE (1972) Primary productivity studjes using merchant vessels in the North Pacufic Ocean In: Takenouchi AY (ed) Biological oceanography of the northern North Pacific Ocean. Idemitu Shoten, Tokyo, p 245-251

Anonymous (1993) Plankton-fish trophic interactions. In: Payne AJL, Pitcher GC (eds) Research highlights 1992/93. Sea Fisheries Research Institute, Department of Environment Affars, Republic of South Africa. Galvin \& Sales, Cape Town, p 19-20

Booth BC, Lewin J, Postel J (1993) Temporal variation in the structure of autotrophic and heterotrophic communities in the subarctic Pacific. Prog Oceanogr 32:57-99

Brodeur RD. Ware DM (1992) Long-term variability in zooplankton biomass in the subarctic Pacific Ocean. Fish Oceanogr 1:32-38

Brooks JL, Dodson SI (1965) Predation, body size, and composition of plankton. Science 150:28-35

Capriulo GM (1990) Feeding-related ecology of marine protozoa. In: Capriulo GM (ed) Ecology of marine Protozoa. Oxford University Press, Oxford, p 189-259

Carpenter SR, Kitchell JK. Hodgson JR (1985) Cascading trophic interactions and lake productivity. BioScience 35 : $634-639$

Cooney RT (1988) Distribution and ecology of zooplankton in the Gulf of Alaska: a synopsis. Bull Ocean Res Inst Univ Tokyo $26: 27-41$

Dagg M (1993) Grazing by the copepod community does not control phytoplankton production in the subarctic Pacific Ocean. Prog Oceanogr 32:163-183

Dagg MJ, Turner JT (1982) The impact of copepod grazing on the phytoplankton of Georges Bank and the New York Bight. Can J Fish Aquat Sci 39:979-990

Dillon PJ, Rigler FH (1974) The phosphorus-chlorophyll relationship in lakes. Limnol Oceanogr 19:767-773

Favorite F, Dodimead AJ, Nasu K (1976) Oceanography of the subarctic Pacific region, 1960-71 Int North Pac Fish Comm Bull 33:1-187

Fisheries Agency of Japan (1986) Data record of Japanese salmon research vessel in 1985: 1-Catch data, 2-Oceanographic data Tokyo (in Japanese)

Fisheries Agency of Japan (1987) Data record of Japanese salmon rosearch vessel in 1986: 1-Catch data, 2-Oceanographir data. Tokyo (in Japanese)

Fisheries Agency of Japan (1988) Data record of Japanese salmon research vessel in 1987: 1-Catch data, 2-Oceanographic data. Tokyo (in Japanese)

Fisheries Agency of Japan (1989) Data record of Japanese salmon research vessel in 1988: 1-Catch data, 2-Oceanographic data. Tokyo (in Japanese)

Fisheries Agency of Japan (1990) Data record of Japanese salmon research vessel in 1989: 1-Catch data, 2-Oceanographic data. Tokyo (in Japanese)

Fisheries Agency of Japan (1991) Data record of Japanese 
salmon research vessel in 1990: 1. Catch data, 2-Oceanographic data. Tokyo (in Japanese)

Fisheries Agency of Japan (1992) Data record of Japanese salmon research vessel in 1991: 1-Catch data, 2-Oceanographic data. Tokyo (in Japanese)

Fisheries Agency of Japan (1993) Data record of Japanese salmon research vessel in 1992: 1-Catch data, 2-Oceanographic data. Tokyo (in Japanese)

Fisheries Agency of Japan (1994) Data record of Japanese salmon research vessel in 1993: 1-Catch data, 2-Oceanographic data. Tokyo (in Japanese)

Fisheries Agency of Japan (1995) Data record of Japanese salmon research vessel in 1994: 1-Catch data, 2-Oceanographic data. Tokyo (in Japanese)

Frost BW (1987) Grazing control of phytoplankton stock in the open subarctic Pacific Ocean: a model assessing the role of mesozooplankton, particularly the large calanoid copepods, Neocalanus spp. Mar Ecol Prog Ser 39:49-68

Fulton J (1973) Some aspects of the life history of Calanus plumchrus in the strait of Georgia. J Fish Res Bd Can 30: 811-815

Hama T, Miyazaki T, Ogawa Y, Iwakuma T, Takahashi M. Otsuki A, Ichimura S (1983) Measurement of photosyntheric production of a marine phytoplankton population using a stable isotope. Mar Biol 73:31-36

Hargrave? BT, Harding GC, Drinkwater KF, Lambert TC, Harrison WG (1985) Dynamics of the pelagic food web in St. Georges Bay, southern Gulf of St. Lawrence. Mar Ecol Prog Ser 20:221-240

Hokkaido University (1986) Data record of oceanographic observations and exploratory fishing No. 29. Hakodate, Hokkaido

Hokkaido University (1987) Data record of oceanographic observations and exploratory fishing No. 30 . Hakodate, Hokkaido

Hokkaido University (1988) Data record of oceanographic observations and exploratory fishing No. 31. Hakodate, Hokkaido

Hokkaido University (1989) Data record of oceanographic observations and exploratory fishing No. 32. Hakodate, Hokkaido

Hokkaido University (1990) Data record of oceanographic observations and exploratory fishing No. 33. Hakodate, Hokkaido

Hokkaido University (1991) Data record of oceanographic observations and exploratory fishing No. 34. Hakodate, Hokkaido

Ikeda T (1974) Nutritional ecology of manme zooplankton. Mem Fac Fish Hokkaido Univ 22:1-97

Ikeda T, Motoda S (1978) Estimated zooplankton production and their ammonia excretion in the Kuroshio and adjacent seas. Fish Bull 76:357-367

Ishida Y (1995) Outine of Japanese salmon research in the North Pacific Ocean in 1994. Reports on the research of Salmon resources in the North Pacific Urran in 1994. National Research Institute of Far Seas Fisheries, Shimizu, Japan. Salmon Report Series No. 39:1-7

Ito J (1964) Food and feeding habit of Pacific salmon (genus Oncorhynchus) in their oceanic life. Bull Hokkaido Reg Fish Res Lab 29:85-97 (in Japanese with English abstract)

Landry MR, Gifford DJ, Kirchman DL, Wheeler PA, Monger BC (1993) Direct and indirect effects of grazing by Neocalanus plumchrus on plankton community dynamics in the subarctic Pacific. Prog Oceanogr 32:239-258

LeBrasseur RJ (1972) Utilization of herbivore zooplankton by maturing salmon. In: Takenouchi AY (ed) Biological. oceanography of the northern North Pacific Ocean.
Idemitu Shoten. Tokyo, p 581-588

Mackas DL, Sefton H, Miller CB, Raich A (1993) Vertıcal habitat partitioning by large calanoid copepods in the oceanic subarctic Pacific during spring. Prog Oceanogr 32: 259-294

Malone TC (1980) Algal size. In: Morris I (ed) The physiolog1cal ecology of phytoplankton. University of Californiả Press, Berkeley, p 433-464

McCauley E. Kalff J (1981) Empirical relationships between phytoplankton and zooplankton biomass in lakes. Can J Fish Aquat Sci 38:458-463

McQueen DJ, Post JR, Mills EL (1986) Trophic relationships in freshwater pelagic ecosystems. Can J Fish Aquat Sci 43: $1571-1581$

Miller CB (1984) Life histories of large, grazing copepods in a subarctic ocean gyre: Neocalanus plume hrus, Neocalanus cristatus, and Eucalanus bungii in the northeast Pacific. Prog Oceanogr 13:201-243

Miller CB (1993) Development of large copepods during spring in the Gulf of Alaska. Prog Oceanogr 32:295-317

Miller CB, Frost BW, Wheeler PA, Landry MR, Welschmever N, Powell TM (1991) Ecological dynamics in the subarctic Pacitic, a possibly iron-l.jmited ecosystem. Limnol Oceanogr 36:1600-1615

Motoda S. Minoda T (1974) Plankton of the Bering Sea. In: Hood DW, Kelley EJ (eds) Oceanography of the Bering Sea, with emphasis on renewable resources. Institute of Marine Science, University of Alaska, Fairbanks, p 207-242

Odate T (1994) Plankton abundance and size structure in the northern North Pacific Ocean in early summer. Fish Oceanogr 3:267-278

Odate T, Yanada M, Mizuta H, Maita Y (1993) Phytoplankton carbon biomass estimated from the size-fractionated chlorophyll a concentration and cell density in the northern coastal waters from spring bloom to summer. Bull Plankton Soc Jap 39:127-144

Parsons TR, Lalli CM (1988) Comparative oceanic ecology of the Plankton communities of the subarctic Atlantic and Pacific Oceans. Oceanogr Mar Biol Annu Rev 23:317-359

Parsons TR, Maita Y, Lalli CM (1984a) A manual of chemical and biological methods for seawater analyses. Pergamon Press, Oxford

Parsons TR, Takahashi M, Hargrave B (1984b) Biological oceanographic processes, 3rd edn. Pergamon Press, Oxford

Roemmich D, McGowan J (1995) Climutic warming and the decline of zooplankton in the Calitornia current. Science 267:1324-1328

Rundstam LG, Aneer G, Hilden M (1994) Top-down control in the pelagic Baltic ecosystem. Dana 10:105-129

Scavia DS, Fahnenstiel GL, Evans MS, Jude DJ, Lehman JT (1986) Influence of salmonine predation ard weather on Iong-term water quality trends in lake Michigan. Can J Fish Aquat Sci 43:435-443

Shiomoto A, Maita Y (1990) Uptake of nitrate and ammonia in the subarctic boundary and adjacent regions of the northwestern Pacific Ocean. Deep Sea Res 37:1887-1897

Smith PE, Eppley RW (1982) Primary production and the anchovy population in the southern Califorma bight: comparison of time series. Limnol Oceanogr 27:1-17

Stockner JG, Antia NJ (1986) Algal picoplankton from marne and freshwater ecosystems: a multidisciplinary perspective Can J Fish Aquat Sci 43:2472-2503

Sverdrup HU, Johnson MW. Fleming RH (1946) The oceans. their physics, chemistry and general biology. PrenticeHall, New York 
Tadokoro K, Davis ND, Ishida Y, Nagasawa K, Sugimoto T (1995) Datı record of zooplankton biomass collected by the NORPAC net aboard the R/V 'Wakatake Maru' in 1991 -1994 in the central North Pacific Ocean and Bering Sea. Reports on the research of salmon resources in the North Pacific Ocean in 1994. National Research Institute of Far Seas Fisheries, Shimizu, Japan. Salmon Report Series No. 39:145-151

Takagi K (1975) Non-selective salmon gillnet for research operations. Int North Pac Fish Comm Bull 32:13-41

This article was submitted to the editor
Takagi K, Aro KV, Hartt AG, Dell MB (1981) Distribution and origin of pink salmon (Oncorhynchus gorboscha) in offshore waters of the North Pacific Ocean. Int North Pac Fish Comm Bull 40:1-195

Taniguchi A (1973) Phytoplankton-zooplankton relationships in the western Pacific Ocean and adjacent seas. Mar Biol 21:115-121

Venrick EL, McGowan JA, Cayan DR, Hayward TL (1987) Climate and chlorophyll a: long-term trends in the central North Pacific Ocean. Science 238:70-72

Manuscript first received: July 2, 1996

Revised version accepted: February 19, 1997 